\title{
Çevresel ve Sosyal Faktörler ile Ruh Sağlı̆̆ı Üzerine Bir İnceleme: Ruh Sağlığı Alanında Sosyal Hizmet Mesleğinin Önemi
}

\section{A Review on Environmental and Social Factors and Mental Health: The Importance of Social Work Profession in the Field of Mental Health}

\author{
Sema Güzel ${ }^{1 *}$, Melek Zubaroğlu Yanardağ ${ }^{2}$ \\ ${ }^{1}$ Burdur Mehmet Akif Ersoy Üniversitesi, Sosyal Politika ve Sosyal Hizmet Tezli YLP Öğrencisi ve Sosyal Hizmet \\ Uzm., Kumluca Devlet Hastanesi, Burdur, Türkiye \\ ${ }^{2}$ Burdur Mehmet Akif Ersoy Üniversitesi, İiBF Sosyal Hizmet Bölümü, Burdur,Türkiye \\ e-mail: semaguze100@gmail.com,mzyanardag@mehmetakif.edu.tr \\ ORCID: 0000-0003-3799-4582 \\ ORCID: 0000-0002-3425-483X \\ *Sorumlu yazar/ Corresponding Author: Sema Güzel \\ Gönderim Tarihi / Received: 17.04.2020 \\ Kabul Tarihi / Accepted: 17.09.2020 \\ DOI: $10.34087 /$ cbusbed. 721875
}

Öz

$\mathrm{Bu}$ çalışmada bireyin ruh sağlığını etkileyen çevresel ve sosyal faktörler ile ruh sağlığı alanında sosyal hizmet mesleğinin önemi ele alınmıştır. İnsanların ruh sağlığını etkileyen pek çok faktör bulunmaktadır. Ruh sağlığı ve hastalıkları uzmanı, kişinin hastalığına yönelik tedavi planını gerçekleştirirken ruh sağlığı ekibinin bir üyesi olan sosyal hizmet uzmanları hastayı etkileyen çevresel ve sosyal faktörleri araştırmakta, gerek görülen konularda müdahale planı hazırlamakta ve mesleki uygulama gerçekleştirmektedir. Son yıllarda özellikle toplum temelli ruh sağlığı modelinin yaygınlaşmasıyla açılan toplum ruh sağlığı merkezlerinde sosyal hizmet uzmanları ruh sağlığ1 alanında daha aktif hale gelmişlerdir. Sonuç olarak; ruh sağlığı alanında önemli profesyoneller olan sosyal hizmet uzmanlarının bu alanda nasıl daha verimli çalışabilecekleri öneriler kapsamında paylaşılmışıtır.

Anahtar kelimeler: Çevresel ve sosyal faktörler, Sosyal hizmet, Psikiyatrik sosyal hizmet, Ruh sağlığı.

\section{Abstract}

In this study, environmental and social factors affecting the mental health of the individual and the importance of social work in the field of mental health are discussed. There are many factors that affect people's mental health. While the mental health and illness specialist carries out the treatment plan for the person's illness, social workers, who are members of the mental health team, prepare a professional intervention plan and apply them in matters deemed necessary to investigate the environmental and social factors affecting the patient. Social workers have become more active in the field of mental health, especially in community mental health care centers, which have been opened with the widespread use of a community-based mental health model. In this paper, within the scope of the suggestions it is also shared that how social workers, who are important professionals in the field of mental health, can work more efficiently in the mental health care field

Keywords: Environmental and social factors, Social work, Psychiatric social work, Mental health.

\section{Giriş}

Bilindiği gibi ruh sağlığı günümüzde genel sağllğın ayrılmaz bir boyutu olarak kabul görmektedir. Ruh sağlığ́ ile ilgili problemlerin toplumda sık görülmesi, yeti yitimiyle sonuçlanabilmesi ve zaman zaman ekonomik zorluklara sebebiyet vermesi gibi nedenlerle ruh sağlığı, toplumsal açıdan büyük bir önem arz etmektedir [1]. Ruh sağlığı bozulan kişilerin beden sağlı̆̆ 1 ve sosyal çevre ile uyumu olumsuz yönde etkilenebilmektedir. Her dört bireyden birinin tüm hayatı boyunca bir veya daha fazla sayıda ruhsal ve davranışsal sorun yaşaması, dünyada yeti kaybı ve erken yaşta ölüme en sik olarak neden olan 10 hastalık arasından 5'ini psikiyatrik hastalıkların oluşturması ruhsal hastalıkları adeta halk sağlı̆̆ açısından öncelikli bir konuma getirmiştir [2]. Ruhsal bozukluk tanımına bakıldığında; kişiye sıkıntı veren veya kişinin işlevselliğini bozan klinik olarak anlamlı olarak değerlendirilebilecek 
davranışsal veya psikolojik sendrom olarak açıklandığı görülmüştür [3]. Ruhsal bir sorun deneyimleyen kişiler yaşamlarını olağan seyrinde devam ettirmekte güçlük yaşamaktadır. Dünya Sağlık Örgütü, sağlığın tanımını yaparken ruhsal ve sosyal durumu da bu tanıma dâhil etmektedir [4]. Özellikle bireylerin ruh sağlığı ve sosyal refahı açısından çevresel faktörlerin de büyük bir önem taşıdığı bilinmektedir. İnsanın ruh sağlığını etkileyen çevresel faktörler; Dünya Sağlık Örgütü tarafından da temel hizmetlere erişimde güçlük/yetersizlik, ayrımcılık, adaletsizlik, cinsiyetler açısından eşitsiz uygulamalar, savaş veya afete maruz kalma vb. olarak belirtilmektedir [5]. Bireyin kendisiyle ve çevresiyle uygun bir denge yakalayabilmesi ruh sağlığı açısından oldukça önemidir. Dengeli bir genetik yapıya ilave olarak uygun bir çevrenin de sağlıği olumlu etkileyeceği açıktır [6] Çevresel boyut da içinde olmak üzere, sağlığın sosyal yönü de en az hastalığın iyileştirilmesi kadar önemlidir. Bunun öneminin anlaşılması üzerine sağlık alanında devletin sosyal hizmet uzmanlarına(sosyal çalışmacılara) ihtiyacı artmaktadır [7]. Sosyal hizmet, zihinsel sağlığa farklı bir sosyal bakış açısı getirir. Bu, yaşam seyri boyunca travma, kayıp ve istismar ile çocukluk ve ergenlik deneyimleri gibi, tamamen tıbbi, hastalık yaklaşımlarında sıklıkla kaçırılan sosyal öncüllerin ve zihinsel sıkıntıların belirleyicilerinin tanınması anlamına gelir [8]. Özellikle çevresi içinde birey perspektifi, ekolojik ve sistem yaklaşımlarından yoğun bir şekilde yararlanan sosyal hizmet disiplini ve bu disiplinin uygulayıcıları olarak sosyal hizmet uzmanları ruh sağlığ alanına bu bağlamı entegre ederler. Türkiye'de ruh sağlığı alanında aktif olarak sosyal hizmet uzmanları görev yapmakla birlikte sayılarının oldukça az olduğu bilinmektedir. Güncel sayılar bilinmemekle birlikte kabaca, Karakuş'un derlediği verilerden hareketle günümüzde en az 1000 sosyal çalışmacının Sağlık Bakanlığı'na bağlı birimlerde (hastane vb.) çalıştıkları bilinmektedir [9]. Bu sayıya özel hastaneler ve özel ruh sağlığı ile danışma merkezlerinde çalışan uzmanlar dahil değildir. Ayrıca Sağlık Bakanlığı'na bağlı olarak çalışan uzmanların tümü hastaların ruh sağlıklarının korunmasına yönelik birim veya merkezlerde görevli değillerdir. Resmi olarak belirlenmiş Personel Dağılım Cetveli (PDC) uyarınca Sağlık Bakanlığına bağlı tüm birimler için 2268 sosyal çalışmacı kadrosu mevcut olarak bulunmaktadır [10]. Amerika Birleşik Devletlerinde (ABD) ise erişilen güncel verilere göre; tüm sektörlerde 707 bin sosyal hizmet uzmanı çalışmaktadır [11]. ABD'de sosyal hizmet uzmanlarının yarısının klinik düzeyde ve eyaletlerde lisanslı bir şekilde birey, aile ve grupların ruh sağlıklarının geliştirilmesine katkı verdikleri bilinmektedir $[12,13]$. Bu çalışmada amaç; ruh sağlığının geliştirilmesinde sosyal ve çevresel faktörlerin öneminin altını çizerek sosyal hizmet mesleğinin bu boyutlarla ilişkisini ortaya koymaktır. Ayrıca ruh sağlığı alanında sosyal hizmet mesleğinin işlevselliğinin nasıl artırılabileceğine yönelik öneriler sunmak çalışmanın bir diğer amacıdır.

\section{Ruh Sağlığını Etkileyen Bazı Sosyal ve Çevresel Faktörler}

İnsan; bedeni, ruhi ve sosyal özellik ve kapasitesini tam anlamiyla yansitabildiği, gösterebildiği ve tüm bu özelliklerini kullanarak davranabildiği oranda kendini anlatabilir ve sağlıklıdır [6]. Kuzu ve Çevik Durmaz'ın çalışmasında sağlık ve hastalık kavramlarının çok boyutlu olarak açıklandığ görülmekte ve sağlığın, sosyal, kültürel, ekonomik, fiziksel ve biyolojik faktörlerden etkilendiği belirtilmektedir [14].

İnsanın ruh sağlığını etkileyen sosyal koşullara bakıldığında "yalnızlık, bir yakının vefatı, ihmal ile aile içi çatışmalar, şiddet ve istismar, gelir düşüklüğü ve yoksulluk, okulda yaşanan zorluklar ile başarısızlıklar ve iş stresi" gibi konuları içerdiği söylenebilir [15]. İnsanlar, yaşamları boyunca birçok zor durumla karşılaşmakta, bunlarla baș etmekte zorlanmakta ve bu durum da onların bedensel ve ruhsal sağlıklarını bozabilmektedir. Kuşkusuz kişinin sosyal çevresi hayatını doğrudan etkiler bu nedenle kişi, davranışlarını o toplumun sosyal kültürel değerlerine göre düzenlemeye çalışır. Bir insanı etkileyen toplumsal kaynaklı streslere baktığımızda savaş, işsizlik, azınlık ayırımları, cinsiyetler arası eşitsizlik, hızlı toplumsal değişmeler, göç, ağır düzeyde toplumsal bunalımlar, sosyal ve ekonomik yoksunluklar ve buna benzer faktörlerin etkili olduğu söylenebilir.

Sosyal faktörlerin çoğu, yapılan araştırma ve çalışmalarda farklı başlıklar altında yer alabilmektedir. Oral ve Tuncay'ın çalışmasında ruh sağlığını etkileyen sosyal faktörler olarak "yoksulluk, işsizlik, aile çözülmeleri-boşanmalar, madde bağımlılığ 1 , korunmaya muhtaç çocuklar ve sokak çocukları" gibi birbiriyle ilişkili problemlerin olduğu belirtilmektedir [16]. Yaşanılan ağır problemlerin/travmanın etkisiyle kişide travma sonrası stres bozukluğu, alkol kullanım bozuklukları, anksiyete ve depresyon oluşabilmektedir. Bunların yanında, yalnızlık başka bir problem alanı olarak baş edilemediği durumlarda "depresyon, sosyal yalıtılmışlık ve intihar" gibi ruhsal problemlere yol açabilmektedir [17]. Yalnız hayatını devam ettirmek zorunda kalan, aile, arkadaş ve diğer insanlarla sağlıklı ilişkiler kuramayan ve çevrelerinden yeterli sosyal desteği görmeyen bireyler, yaşama gücünü daha kolay kaybedebilmektedirler [18].

Kişinin ekonomik koşulları da akıl ve ruh sağlığı üzerinde etkilidir. Yoksulluk özellikle kadın, çocuk ve yaşlıları olumsuz etkilemekte, bu kişilerde "sosyopsikolojik uyum problemi, sosyal becerilerde eksiklik, saldırganlık ya da boyun eğme davranışı, umutsuzluk, içe kapanış, özsayg1 kaybı ve benzeri psikososyal problemlerin; depresyon, somatoform bozukluk ve şizofreni benzeri psikiyatrik rahatsızlıkların daha yaygın olarak gözlendiği bilinmektedir. Tüm bu nedenlerle yoksulluk probleminin ortadan kaldırılmasında k1sa erimli ve geçici önlemlerin yerine, daha kalıcı ve makro boyutta çözümler üretilmelidir [19]. Bu çözümler, uygun sosyal politikaların geliştirilmesi ve bu politikaların uygulanmasında sosyal hizmet profesyonel bakışının korunması yoluyla desteklenmelidir. Jamison ve 
arkadaşlarının araştırmasında yoksulluk veya olumsuz olayların ruh sağlığını ve ekonomik durumu etkileyip etkilemediğinin ayırt edilmesinin gerekliliğinin altı çizilmektedir [20] . Birincil nedensel bağlantı, düşük gelirin zihinsel sağlığı bozduğu şeklindedir. Örneğin, insanlar olumsuz olayların ya da depresyonun bir sonucu olarak yoksulluğa düşmüş olabilir.

Kişilerin ruh sağlığını etkileyen bir diğer faktör olan çevresel faktörler de sosyal faktörlere benzemektedir. Genellikle sorunlu aile ortamları, boşanmış ve parçalanmış aileler, aile üyelerinden birinin hastalı̆̆ da çeşitli bağımlılıklarının bulunması ruh sağlığını olumsuz etkiler. İnsanın yaşadığı çevrede her türlü pozitif ve negatif faktör, insanın büyümesi, gelişmesi, performansı ve kişisel sağlığı başta olmak üzere anatomik, fizyolojik ve psikolojik ayrıca bilişsel ve sosyal yapısında büyük oranda etkili olacaktır [6] . Ruh sağlığına etki eden çevresel faktörler Dünya Sağlık Örgütü tarafından farklı bir sinıflama ile "yetersiz düzeyde temel hizmetlere erişme, ayrımcılık ve adaletsizlik, cinsiyet eşitsizliği ve sosyal eşitsizlik, savaş veya afete maruz kalma" olarak belirtilmiştir [5] .

Öz ve Bahadır Yılmaz'ın çalışmasında ruh sağlığ açısından, fiziki ve cinsel açıdan suistimal, evsizlik, maddi sorunlar, çocuk ihmali, beslenme yetersizliği, akran zorbalığı ve toplumsal şiddete maruziyet gibi durumların çevresel risk faktörü olarak değerlendirilebileceği belirtilmiştir [21]. Ayrıca gürültü kirliliğinin de insanda psikolojik ve fizyolojik olmak üzere sağlık sorunlarına neden olduğu bilinmektedir $\mathrm{Su}$, hava, toprak kirliliği ve radyoaktif maddeler, sevgi ve ilgi noksanlığg, sosyal ilişkilerde aksamalar, seyrelmeler, sanayileşme kaynaklı problemler gibi pek çok olumsuz durum ruh sağlığını bozucu ve yıpratıcı etmenlerdir [6] . İnsanların ruh sağlığını etkileyen bir diğer etken ırkçılıktır. Irkçılığa maruz kalan kişilerde şiddetli stres oluşabilmekte bu durum kişide anksiyete, depresyon ve öfke problemi riskini arttırmakta ve tüm bunlar sonucunda kardiyak problemler de ortaya çıkabilmektedir. Bu grup azınlığın sağlık hizmetlerine erişimde problem yaşamaları, daha düşük maaş almaları ve sigortasız çalışmaları gibi çeşitli dezavantajları bulunmaktadır ve bu durum da onları ruhsal hastalıklara daha açık hale getirmektedir [Akt. 16]. Sosyal dışlanmanın içinde toplum içinde farklı kültürden gelenler, LGBTİ bireyler, azınlıklar, sosyal yoksunluk içindekiler, hayat kadınları, mülteciler, göçmenler, yaşlılar, evsizler, engelliler, sokakta yaşayan ev çalışan çocuklar, akıl ve ruh sağlığı problemi bulunan bireyler, ev içi şiddet mağdurları, afetzedeler vb. bireyler gibi çok çeşitli insan grupları bulunmaktadır [22].

Beşeri etkenler kadar doğal olaylar da ruh sağlığını etkilemektedir. Ülkemizin de güçlü fay hatları üzerinde bulunması, yakın bir tarihlerde büyük depremler yaşaması gibi nedenlerle de ruhsal travmaya neden olan kaynaklar bir hayli fazla görünmektedir [21]. Yine salgın hastalık olayı da ruhsal durumu etkilemektedir. Ulusal ve uluslararası görülme durumuna göre epidemik ve pandemik olarak değerlendirilmektedir. Pandemi durumunda kişiler pek çok stresle karşı karşıya kalmaktadır. Hastalığın bulaş durumunda insanların yakınlarına bulaştırma kaygıları, yakınının kaybı, gelecek kaygısı, olumsuz duygu ve düşünce, kendini dış dünyadan soyutlama, içe kapanma, çaresizlik, gerginlik, huzursuzluk, iletişim çatışmaları vb. pek çok duygu ve düşünceye sahip olabilmekte ve bu durum onların ruh sağlığını derinden etkileyebilmektedir. Salgın durumlarında da insanlar bir yerden başka bir yere göç etme davranışına yönelebilmektedir. Salgın dışında çoğunlukla bireyleri göçe zorlayanlar savaşlar, şiddet olayları, zorlayıcı yaşam olayları ruh sağlığını olumsuz etkileyen çevresel faktörlerin başında yer almaktadır [14]. Göç, yer değiştirmeden de öte, sosyal çevre açısından değişimin gerçekleştiği ve bu yönüyle bireyleri genellikle yerleşilen toplumda adaptasyon problemleriyle karşı karşıya bırakan ve geçici veya kalıcı ruhsal problemlere neden olabilen bir süreci ifade etmektedir [23] . Göçle beraber adaptasyon güçlügüünün yanında yeni sosyal çevrede gelişen farklı yaşam şekli, yeni kültüre uyum sorunları, dil bariyeri, sosyal destek yetersizliği, ekonomik problemler ve zor çalışma koşulları bu bireylerin psikososyal problemlerini öne çıkarmaktadır. Özellikle kadın göçmenlerin yaşadıkları sosyoekonomik güçlükler, sağlık hizmeti ve psikiyatrik hizmetleri daha az kullanmalarına neden olmaktadır [24]. Göç süreci kadınlar dışında diğer grupları da kuşkusuz etkilemektedir. Göç sürecinde yaşanan yoğun stresör durumlarla baş etme mekanizmaları yetersiz olan bireyler, depresyon, anksiyete, uyum problemleri, travma sonrası stres bozukluğu, şizofreni gibi ruh sağlığ 1 sorunlarına da daha yatkın olmaktadırlar [25] . Yaşadığı travmatik deneyim sonrasında kendisini bir takım sıkıntılar içerisinde bulan bireyin ailevi, sosyal, psikolojik ve tıbbi destek ihtiyaçlarının karşılanması hayati bir önem taşımaktadır. Düşünüldüğünde doğal ve insan eliyle oluşturulmuş bir çok travmatik olaya maruz kalan bireyden söz etmek mümkündür [26]. Travmaların atlatılması ve iyilik halinin yeniden sağlanması noktasında sosyal hizmet, disiplin ve eğitimine önemli bir rol düşmektedir [27]. Bu roller; vaka yönetimi, kaynaklarla buluşturma, özellikle travma nedeniyle sosyal işlevselliği ciddi şekilde bozulmuş bireyler için savunuculuk, klinik eğitimi olan sosyal hizmet uzmanları açısından psikoterapi uygulama olarak sıralanabilir.

Yukarıda sözü edilen pek çok olayı yaşayan ve benzeri durumlara maruz kalanların karşılaştığı bir diğer sorun da stigmatizasyondur. Etiketleme (stigmatizasyon) hastanın ve ailesinin durumunu olumsuz etkileyen bir durumdur. Başka bir ifadeyle, bireyin içinde yaşadığ topluluğun/toplumun "normal" olarak kabul ettiği ölçülerin dışında kabul edilmesi nedeniyle, toplumdaki diğer bireyler tarafından bireye sahip olduğu saygınlığı azaltıcı yönde bir atıfta bulunulmasıdır. Etiketlemeye maruz kalan bireye, gerçeğe dayanmaksızın, ismini kötüye çıkaran ve utanç verici bir etiket yüklenmektedir [28] . Etiketlemeyle beraber benlik saygısı, ilişkiler için bir tehdit oluşturabilir ve psikiyatrik hastaların iş olanaklarını sınırlandırabilmektedir. Özellikle iş arama ve işe başvuru aşamalarında düşük benlik saygısı işvereni olumsuz yönde etkileyebilir. $\mathrm{Bu}$ durum, işe alan 
açısından ruhsal hastalığı olan bireyleri daha ilk aşamada eleyen bir durum yaratır. Ayrıca etiketlenme nedeniyle birey ve ailesi yaşadıkları çevreden soyutlanarak yalnızlaşırlar. Etiketlenme kaygısı hasta ve ailenin tedaviye başvurmalarını da geciktirebilir. Bu doğrultuda denilebilir ki toplumun ruhsal hastalığı bulunanları damgalayıcı ön yargıları ve inançları ile negatif tutumları azaldıkça bu bireylerin kendilerini stigmatize olmuş hissetmeleri azalacaktır [29]. Damgalanmayla karşı karşıya kalan ruhsal bozukluğu bulunan hasta ve hasta yakınının belirgin duygusal zedelenme yaşanmakta ve benlik saygıları azalmaktadır, aile ilişkileri zarar görmekte, toplumsal ilişkiler, arkadaş edinme ve sürdürme güçlükleri ortaya çıkmaktadır [30].

Bunların yanında yaşanılan çevrede ve toplumda cinsiyet ayrımcılığının yaygın olması ve toplumsal cinsiyet rollerinin baskısı sonucu kadınların ruh sağlığı olumsuz etkilenebilmektedir. Demirgöz Bal'ın araştırmasında kadın ve erkek için toplumun belirlediği rol ve sorumluluklara toplumsal cinsiyet adı verildiği, toplumsal cinsiyet eşitsizliği nedeniyle kadınların daha sağlıksız, daha eğitimsiz oldukları, daha düşük seviyelerde istihdam oranına sahip oldukları ve daha az gelir getiren işlerde çalıştıkları belirtilmiştir [31]. Kadınlar, yaşamları boyunca değişik dönemlerde cinsiyet eşitsizliğinden dolayı farklı risklerle karş1laşabilmektedir. Bunlar; gerek iş dünyasındaki riskler gerekse diğer sosyal alanlarda toplumsal cinsiyet açısından karşılaşılan riskleri içine alır. Cinsiyet eşitliği, gerek ulusal gerekse uluslararası pek çok düzenlemeyle güvence altında gibi görünse de tüm dünyada tam olarak toplumsal cinsiyet eşitliğini sağlayabilen hiç bir ülke bulunmamaktadır [32]. Toplumsal cinsiyet eşitsizliğ sonucu kadınlarda birçok sağlık sorunu oluşabilmektedir [33]. Bunların dışında madde bağımlılı̆̆ı olan, adölesan gebe, kronik veya ruhsal hastalığı bulunan kişilerin, kalabalık ailede yaşayanların, göç etmek zorunda kalan, ölüm, hastalık veya ayrılık deneyimlemiş, düşük sosyoekonomik statüde olan veya ev içi şiddete sahip ailelerin erken bir dönemde tespit edilerek olumlu ruhsal gelişimi destekleyecek şekilde yardım edilmesi oldukça önemlidir [21].

Görüldüğü üzere sosyal ve çevresel faktörlerin ruh sağlığı üzerinde etkili olduğuna ilişkin çok sayıda destekleyici çalışma bulunmaktadır. Bu nedenle ruh sağlığı alanında bu boyutların tedavi yaklaşımında göz önünde bulundurulması ve bunlara etki edebilecek profesyonel uygulamaların etkinleştirilmesi ve artırılması büyük önem taşımaktadır.

\section{Ruh Sağlığında Çevresel ve Sosyal Faktörler ve Sosyal Hizmet Mesleği İlişkisi}

Bilindiği gibi sağlık alanında; fiziksel, duygusal, psikolojik ve sosyal boyutlar göz önünde bulundurulmalı ve hastalıkların tedavisinde bu boyutların tümünün dahil edildiği bir yaklaşım sergilenmelidir [34]. Her psikiyatrik hastalık, çok sayıda faktörün etkisi ile meydana gelmektedir ve bireyler aynı tanıyı almış olsa bile hastadan hastaya farklılaşabilen durumlara rastlanabilmektedir, çünkü her birey farklı özelliklere sahiptir [35]. Bu noktada da ekip çalışmasının önemi ortaya çıkmaktadır.

Psikiyatride ekip çalışması yaklaşımı, günümüzde psikiyatrik hastalıkların bütüncül bir şekilde ele alınmasına olanak veren önemli bir durum olup böylece hastalıkların sadece tıbbi yönden değil aynı zamanda kişisel, çevresel, sosyal ve kültürel faktörlerle beraber değerlendirilmesini sağlamıştır [36]. Karadağ da sağlığın fiziksel, ruhsal ve sosyal boyutlarıyla ayrılmaz bir bütün olduğunu, sorunlara çözüm üretmek için meslek elemanlarının ilgili diğer mesleklerden profesyonellerle ekip çalışması dahilinde işbirliği yapması gerektiğini belirtmiştir [37]. Sosyal hizmet uzmanının da bu ekibin bir parçası olması oldukça önemlidir. Sosyal hizmet uzmanının bu noktada biyopsikososyal yaklaşımla bütünleşen "çevresi içinde birey" bakış açısını mesleki uygulamalarında benimsemesi esastır [38].

İnsan, bulunduğu sosyal çevreden doğal bir şekilde etkilenmektedir. Sosyal hizmet, temelde kişi ve onu kuşatan sosyal çevresi arasındaki etkileşime sistemik olarak ve güçler perspektifi temelinde odaklanır. Bilindiği gibi güçler perspektifinde çevrenin önemi vurgulanmakta ve bireyleri hastalığa sahip varlıklar olarak tanımlamaya karşı çıkılmaktadır. Müracaatçının motivasyonunun onun güçlerine odaklanılarak artırılabileceği savunulur. Müracaatçı ile işbirliği ve onun güçlerine odaklanma esastır [39]. Psikiyatri ise ruhsal hastalıkların tanısında, tedavisinde ve toplum ruh sağlığının korunması noktasında birincil düzeyde sorumluluk taşımaktadır [40]. Bu sebeple, tıbbi problemlerde bütüncül bir yaklaşım benimsenmekte ve bu noktada tıbbi sosyal hizmet uzmanı birbirine etki eden söz konusu boyutların dengeli bir şekilde ele alınmasını ve soruna müdahale edilmesini sağlamakla görevlidir [34]. Sosyal hizmet uzmanları ruhsal hastalığı bulunan, hastanede veya ayaktan tedavi gören, rehabilitasyon çalışmalarına dahil olan hastaların bakımını destekler, tedavi sağlar ve koordine eder, bireyi çevresi içinde ve bütüncül olarak değerlendirir, hastaların yaşam kalitelerini artırmayı hedefler [41]. Hastanede yürütülen sosyal hizmet uygulamaları, tıbbi bakım ve tedavi sisteminin daha insancil, daha etkili şekilde hizmet sunmasında, ayrıca hastalıklara doğru tanı konulması ve hastalıkların çok yönlü tedavisinin yapılabilmesi için gereklidir [34, 42].

Sosyal hizmet uzmanları ruh sağlığını etkileyen sosyal ve çevresel etkenleri tespit ederek gerek risklerin önlenmesi gerekse tedavi sürecinde hastanın durumunun değerlendirilerek gerekli müdahalenin yapılmasını sağlar. İnsanların karşılaştığ 1 ve ruh sağlıklarını etkilediği düşünülen sosyal ve çevresel faktörlere yönelik gerekli çalışmaları yürütür.

Küresel çapta yaygın bir sosyal sorun üzerinden açıklama yapılacak olursa; yoksul bireyler, barınma, beslenme, eğitim, korunma gibi birçok ihtiyaçlarını yeterli düzeyde karşılayamamakta bu durum da onların psikososyal sağlığını olumsuz yönde etkileyebilmektedir. Yoksulluğa karşı farklı tepkiler veren insanlardan bazıları yoksullukla baş edebilirken bazıları daha çabuk 
ümitsizliğe düşmekte ve süreğen endişelerden dolayı öz benlikleri zarar görebilmektedir. Bu bağlamda sosyal hizmet mesleği yoksul bireylere yönelik çalışmalar yürütmektedir. Dezavantajlı ve hassas/incinebilir bireylerin, grupların ve ailelerin hak savunuculuğunu yapan bir meslek olarak sosyal hizmet, insan hakları ve sosyal adalet temeline dayanarak yoksullukla mücadelede önemli bir yer teşkil etmektedir [43]. Sosyal hizmet uzmanları yoksulluk içindeki bireyin ve ailesinin durumunu inceledikten sonra, bireyin gelir elde edebileceği bir ișe sahip olmasını sağlayıcı müdahalelerde bulunma, diğer kurumlarla işbirliği kurma, bireye sosyal yardım sağlama, aile danışmanlığ hizmeti verme veya başka kurumlardan bu hizmeti sağlama gibi pek çok çalışma yürütürler. Makro düzeyde ise, yoksullukla ilgili projeler ve sosyal politika çalışmalarına da katkıda bulunurlar.

Savaş, deprem vb. durumlar sonucu göç etmek zorunda kalan göçmenlerin de ruh sağlığı büyük oranda olumsuz yönde etkilenebilmektedir. Dış göç ya da iç göç sonucu yaşadığ 1 alıştığı yeri terk ederek yeni bir düzen arayışında olan göçmenler, sosyal hizmetlere gereksinim duymakta doğrudan ve dolaylı uygulamalarla bu hizmetlerden yararlanmaktadır [44]. Göçmenlerin yaşadığ 1 ruhsal problemler, göçmenlerin sosyoekonomik ihtiyaçlarının tespit edilmesi ve gerekli psikososyal yardımın sağlanması için sosyal hizmet uzmanları gerekli çalışmaları yürütür. $\mathrm{Bu}$ çalışmalar, sosyal hizmet uzmanının; bağlantı kuruculuk, eğiticilik, savunuculuk, vaka yönetimi, danışmanlık rolleri kapsamında göçmenlerin sorun tiplerine göre şekillenir. Bağlantı kurucu rol çerçevesinde sosyal yardım sağlamaya yönelik mesleki çalışma yapma, aynı şekilde müracaatçının iş bulabilmesi için bağlantı kurucu rolü kullanma örnek olarak verilebilir.

Ruh sağlığı problemi yaşayan bireylerin karşılaşabildikleri sorunlardan biri de evsizliktir. Evsizlik de kendi başına bir çevresel sorundur. Evsizlik, birden çok değişkene sahip ve birçok değişkenden etkilenen bir sosyal sorun olarak görülebilir. Evsizlik başlı başına bir sosyal problem olma özelliğindedir ve başka sosyal sorunların kimi zaman bir sonucu kimi zaman da başka sosyal problemlere yol açan bir sorun olma özelliği taşımaktadır [45]. Meslek elemanları evsizlere yönelik sosyal hizmet yaklaşımında bireylerin güçlendirilmesi, evsiz bireylerin topluma yeniden entegre olmaları ve bağımsız olarak yaşamlarını idame ettirebilmeleri noktasında yardımcı olmaya çalışmaktadır [46]. Bu noktada sosyal hizmet uzmanları evsiz bireyin de onayı ile varsa ailesi veya yakın çevresiyle bağlantı kurma, bozulmuş kişilerarası ilişkilerini yeniden düzenleme, barınma ihtiyacını evsiz bireyle birlikte değerlendirerek çözüm seçeneklerini konuşma, evsiz bireyin sağlık taramalarının sağlanması için girişimde bulunma, evsiz bireyin sosyal işlevselliğinin yeniden müracaatçı katılımı yoluyla artırılması için müdahalelerde bulunma gibi çalışmalar yapabilirler.

Bir başka çevresel faktör olan afetlerle ilgili de, özellikle afet sonrası süreçte insanlar ruhsal travmanın yanı sıra pek çok temel gereksinimlerine de ulaşamamaktadırlar.
$\mathrm{Bu}$ noktada yiyecek, giyim, barınma gibi ihtiyaçları sosyal hizmet uzmanları tespit etmekte ve krize müdahale yaklaşımı ile afetzedelere gerekli desteği ve psikolojik ilk yardımı sağlamaktadırlar. Psikolojik ilk yardım, afet sonrasında veya yaşanan bir travmatik olay (kaza, terör saldırısı vb.) sonrasında müracaatçılara erken dönemde acil olarak verilen bir tür psikolojik desteklemedir. Sosyal hizmet uzmanlarının travma sonrası uygulanan psikoterapilerle ilgili ileri bir eğitimleri yoksa (EMDR - Göz Hareketleriyle Duyarsızlaştırma ve Yeniden İşleme Terapisi- vb.) temel görüşme tekniklerini (dinleme, empati kurma, yansitma vb.) kullanması ve kişinin kendini ifade etmesine olanak sağlayıcı bir ortam sağlaması önemlidir. Detaylandırmak gerekirse sosyal hizmet uzmanları, akut dönemde öncelikle kişiye odaklanarak kişinin problem çözme, baş etme ve gelişimsel kapasitesini geliştirmeye çalışır. Daha sonra gerekli kaynaklar hizmetler ve firsatlarla kişileri buluşturur ve son olarak sisteme odaklanarak bireyin ihtiyaçlarını daha etkin karşılamak için sistemde değişim yapma yollarını araştırır [47]. Bu bağlamda yapılan çalışmalar ayrıca, afetzedelerin ruh sağlıklarını korumaya ve ruhsal hastalıkların erken dönemde tespit edilerek gerekli müdahalelerin (vakaların yönetimi ve takibi, ihtiyaç tespiti, psikososyal danışmanlık vb.) veya havalelerin yapılmasına katk1 verebilmektedir. Sosyal hizmet uzmanlarının afetzedelerle sonraki görüşmelerinde gerekiyorsa diğer meslek elemanlarına (psikiyatrist, klinik psikolog vb.) havalede bulunmaları uygun olacaktır.

Sosyal hizmet uzmanlarının ruh sağlığı alanında en çok hizmet verdikleri konulardan bir tanesi de daha önce değinildiği üzere etiketleme olarak belirtilebilir. Etiketlenmeye maruz kalan marjinal azınlıklarla, eşcinsellerle, suça sürüklenen çocuklarla, hükümlülerle, alkol, madde ve diğer bağımlıkları olanlarla yine psikososyal odaklı çalışmalar yüz yıldan fazla süredir yapılmaktadır [16]. Bu grupların yaşadığ 1 sosyal baskı ve ayrımcılıkla mücadele edici çalışmalar yürütülmesi gereklidir. Sosyal hizmet mesleği açısından, kısa vadede ırkçılık mağdurlarının haklarının sağlanması ve savunulması konularında, uzun vadede ise koruyucuönleyici uygulamalar ile toplumsal düzeyde irkçılığın tamamen ortadan kaldırılmasını amaçlayan çalışmalar gerçekleştirmesinin gerekli olduğu söylenebilir [48]. Sosyal hizmet uzmanları bu bağlamda bireylerde, gruplarda ve daha büyük topluluklarda ruh sağlığının geliştirilmesi adına yenilikçi çalışmalar üretmelidirler.

\section{Ruh Sağlığı Alanında Sosyal Hizmet Mesleğinin Yeri}

Ruh sağlığı alanında sosyal hizmet uygulamalarının amacı bilindiği gibi, hasta ve ailesine yönelik psikososyal iyileştirme, birey, aile ve toplumsal düzeylerde refah düzeyini yükseltme, bireylerin hayatları üzerindeki gücü ve kontrolü arttırma ve sosyal adalet ilkelerini geliştirme üzerinde odaklanır [16]. Başer ve arkadaşlarının çalışmasında ruh sağlığı alanında sosyal hizmet ikinci ya da eğreti bir alan değil, birincil işleve sahip, önleyici ve koruyucu rolleri olan, tedavi sırasinda 
ve sonrasında psikiyatri alanındaki hizmetlerin etkililiğini temin eden bir alan olarak tanımlanmıştır [49]. Ruh sağlığı alanındaki sosyal hizmet uygulamalarını tanımlayan psikiyatrik sosyal hizmet; kişisel problemler, kişilerarası problemler, ailevi problemler, sosyal çevre ve sosyal işlevsellikle ilgili problemler gibi pek çok konuda birey, aile ve gruplara destek sunmaktadır. Psikiyatrik alanda sosyal hizmet mesleğinin özgün olarak kendisine has rol ve sorumlulukları bulunmaktadır. Sosyal hizmet uzmanı, psikiyatrik iyileştirme sürecinin tüm aşamalarında rol alır. Mesleki uygulamalar genel sosyal hizmet bilgisine, değerlerine ve becerilerine dayalı olarak yapılabildiği gibi, özel, psikiyatrik sosyal hizmet bilgi ve becerisinin kullanıldığı müdahaleler de yapılabilir [16]. Psikiyatrik sosyal hizmet uzmanları hiçbir zaman klinik/hastane duvarları arasında sınırlandırılmış olarak çalışamaz. Böyle bir çalışma mesleğin misyonuna uygun değildir. Sosyal hizmet mesleği, ruh sağlığı alanında, bireysel baş etme kapasitelerinin, çevresel faktörlerle birlikte güçlendirilmesi ve toplumsal bilincin geliştirilmesini içeren çok boyutlu sorumluluğu olan bir meslektir [40] . Bu yönüyle psikiyatrik destek ekibindeki diğer meslek gruplarından farklılaşmakta ve özgün konumunu korumaktadır.

Psikiyatrik tedaviye ihtiyaç duyan birey hakkında; yaşamı, sosyo-ekonomik durumu, aile ve çevresi ile olan ilişkisi hakkında detaylı bilgi edinilmesi de çok yönlü bir tedavi programının oluşturulmasında önemlidir. Sosyal hizmet uzmanları tarafından yapılacak ev ve iş yeri ziyaretleri sonucunda hazırlanacak sosyal inceleme raporu ile hasta ve yaşadığı çevre konusunda gerekli detaylı bilginin tedavi ekibine sunulması sağlanmış olmaktadır [50]. Psikiyatrik sosyal hizmet uzmanları genel olarak, psikososyal ve risk değerlendirmeleri, bireyle ve grupla çalışma, psikoterapi, psikoeğitim, krize müdahale, bakım koordinasyonu ve rehabilitasyon hizmetleri vb. mesleki çalışmaları yerine getirmektedir [41]. Ayrıca değerlendirme yapma, psikiyatristin koyduğu tanı 1şığında psikososyal danışmanlık hizmeti verme, müracaatçı odaklı savunuculuk, konsültasyon ve tedavinin sonucunu değerlendirme gibi görevleri bulunmaktadır [16].

Psikiyatrik sosyal hizmet alanında rol alan sosyal hizmet uzmanları iyileşme yaklaşımının makro ayağında da etkin rol almaktadır. İyileşme yaklaşımının makro boyutu, birey ve toplulukların çok katmanlı ve birbiriyle etkileşim halinde olan sistemlerle çevrili olduğunu vurgulayan sosyal hizmet disiplini için çok önemlidir [51]. Büber ve arkadaşları da mikro ve mezzo boyutlarda bireyi, ailesini ve çevresini kapsayan müdahalelerde bulunmak gerekirken makro boyutta ise sürece toplumun da katılımını amaçlayarak kamu kurum ve kuruluşları, sivil toplum örgütleri ve politika yapıcılar ile işbirliği içerisinde çalışmalar yürütecek müdahalelere ihtiyaç olduğunu bildirmişlerdir [52].

Makro boyut bağlamında psikiyatrik sosyal hizmet özellikle toplum ruh sağlığ yaygınlaşmaya başlamasından sonra etkin bir şekilde uygulanmaya başlanmıştır. Toplum temelli hizmetler her ne kadar çeşitli olsa da ruh sağlığı literatürü ve sosyal hizmet mesleği açısından Türkiye'de dört temel çalışma alanı belirlenebilmektedir. Bunlar, koruyucu önleyici çalışmalar, ruh sağ lı ̆ ${ }_{1}$ alanında bilgilendirme, ruh sağlığ1 sorunu olan kişilerin çevresinin güçlendirilmesi ve damgalama ile mücadeledir [49]. Toplum temelli ruh sağlığ1 anlayışı; hastalık nedeniyle işlevselliklerindeki azalmanın önüne geçilmesi, takip ve tedavilerinin sürdürülmesi amacıyla; hastanın evinde, mahallesinde veya işyerinde temel yaşam ihtiyaçlarını karşılamayı, sorunlarla başa çıkma becerilerini geliştirmeyi ve gerekli destek sistemlerini devreye sokmayı hedefler [53]. Bireylerin, ruhsal sorunlarının üstesinden gelmelerine yardımc olmak ve hastalık nedeniyle kaybettikleri toplumsal rollerini yeniden kazanmalarını sağlamak amaciyla yapılan çalışmaların hepsi, toplum ruh sağlığg hizmetleri içerisinde yer almaktadır [54]. Bu modelde ciddi ruhsal hastalığı olan hastaların tedavi ve rehabilitasyonlarının hastanelerde değil, kendi yaşadıkları çevrede yapılması, minimum destekle sık hastane yatışlarının önlenmesi amaçlanmaktadır [55].

Sosyal hizmet uzmanlarının toplum ruh sağlığ alanındaki görevlerini genel olarak kategorize etmek gerekirse ruhsal risk taraması ve araştırma, sosyal içerme, hizmet geliştirme ve toplum eğitimi etkinliklerinden bahsedilebilir. Toplum ruh sağlı̆̆ hizmetleri kapsamında ailelere ise eğitim ve danışmanlık hizmeti verilmekte bunun dışında meslek elemanlarının rehabilitasyon ayağında da önemli işlevleri bulunmaktadır. Toplum ruh sağlığı merkezleri toplumsal kaynakları hasta ve ailelerinin talepleri doğrultusunda kullanmakta, çevresel faktörleri dikkate almakta, hastaya ve ailesine ihtiyac1 olan psikososyal desteği sağlamaktadır [56]. Sosyal hizmet değerlendirme süreci, biyomedikal faktörlerin etkisini ve mental bir bozukluk yaşayan bireyin psikolojik, sosyal ve diğer ihtiyaçlarını dikkate almaktadır. $\mathrm{Bu}$ çerçevede sosyal hizmet uzmanları, bireyin haklarının önceliğine saygı gösterir ve bireyler ile ailelerinin hayatlarının kontrolünü sürdürmelerine ve iyileşme ve refah için sorumluluk almalarına yardımcı olmak için beceri ve güven geliştirmeye çalışırlar [57]. Zihinsel sağlığın sosyal modeli, toplumsal yaşamın temel bir yönüdür ve sosyal hizmet uzmanlarının meşru olarak akıl sağlı̆̆ hizmetlerine belirgin ve benzersiz katkısı göz önünde bulundurulmalıdır [58]. Toplum Ruh Sağlığı Merkezi Uygulama Rehberinde de "Sosyal çalışmacıların, psikologların ve hemşirelerin ortak görevleri şu şekilde belirlenmiştir. Hizmet alanlara ve ziyaretçilere TRSM'nin amacı ve çalışmalarl ile ilgili bilgi verilmesi, hizmet alanlara ve ailelerine yönelik psikososyal müdahalelerin yürütülmesi, gezici ekip faaliyetlerinin yürütülmesi, yatakl tedavi gerektirecek bir kötüye gitme durumunda hastanın ilgili kliniğe nakline destek verilmesi, veri formlarının doldurulması, ölçeklerin (skala) izlenmesi, istatistik/veri toplanmasi ve değerlendirilmesi merkeze devam etmeyen hastaların aileleriyle temasa geçilmesi, gerektiğinde merkezden taburculuk süreçlerinin yürütülmesi, kamuoyu farkındalığının artırılması ve damgalamayla mücadele faaliyetlerinin yürütülmesinin săglanmasıdır" [59]. 
Sağlık Bakanlığının 16/02/2011 Tarih ve 7364 Sayılı Makam Onayı ile yürürlüğe giren Toplum Ruh Sağlığ Merkezleri Hakkında Yönerge' de de sosyal çalışmacının görev ve sorumlulukları şu şekilde belirtilmiştir [59]: "Merkezin sorumlu olduğu bölgedeki hastaların tespit edilmesi ve merkeze kaydını temin etmek için ilgili kurum ve kişilerle irtibat kurulmast, hasta ve/veya yakınlarıyla irtibat kurulmass ve merkez hakkında bilgi verilerek merkeze davet edilmesi, hastaneye yatışı gereken, bakıma muhtaç ya da çalışabilecek duruma gelmiş hastaların; hastane, bakım kurumu, korumalı iş yeri ihtiyacına cevap verebilmek için ilgili kurumlarla irtibat kurulmast, damgalama karşıtı çalışmalar için kurumlar arası işbirliğini sağlanması ve geliştirilmesi, hastaların sosyal ve hukuki haklarl konusunda bilgilendirilmesi karşılaştıkları güçlüklerin çözümlenmesinde destek hizmetinin verilmesi, sivil toplum kuruluşlart ve diğer kurumlarla ilişkileri sağlanması”. Toplum ruh sağlığ merkezi çalıșmaları kapsamında sosyal hizmet uzmanları kısa bir anlatımla; multidisipliner bir anlayış çerçevesinde damgalama karşıtı mesleki çalışmalar yapar, sosyal işlevsellik ve sosyal refahın artırılmasına yönelik çalışmalara aktif bir şekilde destek verir. Sosyal hizmetin birey, aile, grup ve toplum (mikro, mezzo ve makro) düzeyindeki uygulamaları uzmanların müracaatçılarla çalışırken durumu birçok yönden değerlendirebilmelerini ve mesleki müdahalelerini birçok açıdan organize etmelerini sağlamaktadır [15]. Özellikle şizofrenide damgalanmanın önlenmesi ve azaltılması için yapılacak sosyal politika uygulamalarında; damgalanmanın sebepleri ve bireyler üzerindeki sonuçları kapsamında araştırmalar yapmak, projeler geliştirmek, toplumu şizofreni konusunda eğitmek, damgalanmanın sonuçları konusunda toplumdaki bireylerin bilgi ve bilinç kazanmalarını sağlamak, şizofreniye yönelik çalışan ilgili kurum ve kuruluşlarda personeli bilgilendirici çalışmalar yapmak sosyal hizmet uzmanlarının önemli görevleri arasında siralanabilir [52]. Damgalanmayla mücadeleye yönelik müdahaleler/uygulamalar kronikleşebilen bu rahatsızlıkların tedavisini kolaylaştırabilecektir [61]. Ruhsal hastalığa yönelik olumsuz inançların varlığı nedeniyle de ruhsal hastalığı olan insanlar hem insan hakları hem de sosyal adalet değerlerine aykırı uygulamalarla karşılaşabilmektedir. $\mathrm{Bu}$ tür uygulamalarla mücadele etmek sosyal hizmet uzmanının en temel görevlerindendir [62].

Ruh sağlığı alanında çalışan sosyal hizmet uzmanının rollerinden biri de ruh sağlığına ilişkin politikaların oluşturulmasına katkı sağlanmasıdır. Sosyal hizmet mesleğinin diğer meslek gruplarına göre özgün yönleri bulunmaktadır. $\mathrm{Bu}$ özgün yanlarının sosyal politika oluşturulmasında önemli olduğu bilinmelidir [63]. Sosyal hizmet uzmanları, değişimin hem bireysel düzeyde hem de diğer alanlarda gerçekleşmesi gerekip gerekmediğini analiz etmeye odaklanır. Bu interaktif ve sistemik analiz, sosyal hizmeti ruh sağlığ sektöründeki diğer sağlık mesleklerinden ayırmaktadır. İnsan hakları ve sosyal adalete olan bağliliklariyla sosyal hizmet uzmanları, müracaatçıların ayrımcılığa ve istismara karşı haklarını savunmaktadır. Terapötik müdahaleler ve hizmet ile desteklerin seferber edilmesi yoluyla, sosyal hizmet uzmanları, zihinsel sağlı ve bireylerin sosyal işlevselliklerini geliştirir, iyileşmeyi ve esnekliği teşvik eder ve damgalamayı azaltmayı amaçlar [57]. Tüm bu roller ve amaçlarıyla sosyal hizmet mesleğinin ruh sağlığı alanında büyük bir yere ve uygulama alanına sahip olduğunu söylemek mümkündür. Sosyal hizmet, ruh sağlığı alanındaki diğer mesleklerden ayrılan bağlamı odağında hem bireyin hem de büyük ölçekte toplum ruh sağlığı açısından önemli katkılar sunmaktadır.

\section{Sonuç}

Psikiyatrik sosyal hizmet; gerek ruh sağlığı problemi yaşayan bireylerin ve yakınlarının gerekse diğer bakım verenlerin yaşadıkları sorunların azaltılması, hastanın tedavi ve rehabilitasyonunun sağlanması, aileye bu süreçte gerekli danışmanlık ve eğitimin verilmesi, hastanın sosyal işlevselliğinin geliștirilmesi ve toplumda aktif rol almasını hedeflemektedir. Sosyal hizmet uzmanları özellikle ruhsal ve sosyal iyilik durumunu sağlamaya yardımcı olmaktadır. Ruh sağlığına etki eden birçok faktörün bulunduğu çeşitlilik karşısında bu faktörlerin incelenmesinde, ruh sağlığının tedavi edilmesinde, koruyucu-önleyici hizmetlerin geliştirilmesinde farklı bilgi ve deneyime sahip olan sosyal hizmet uzmanları yadsınamaz bir öneme sahiptir [37].

Sosyal hizmet uzmanı bu çalışma kapsamında bahsedilen sorun alanlarıyla ilgili olarak hem koruyucu önleyici hem de durum/olay gerçekleştikten sonra durum tespiti yaparak kişilerin ihtiyaç durumlarına göre gerekli sosyal hizmet müdahalesini planlama ve uygulama noktasında destek çalışmalarında bulunmaktadır. Sosyal adalet ve demokrasi çerçevesinde kaynakların artırılması ya da iyileştirilmesi için sivil toplum kuruluşları ve dezavantajlı gruplarla ittifak kurularak güç yapılarının yeniden düzenlenmesi bağlamında çalışmalar yapmaktadır [64] .

Bu çalışmada sunulan tüm bilgiler ışı̆̆ında Türkiye'de ruh sağlığı alanında sosyal hizmet mesleğinin işlevselliğinin artırılmasına yönelik aşağıdaki öneriler sunulmaktadır:

Sosyal hizmet uzmanları insanın ruh sağlığını etkileyen sosyal ve çevresel sorunlarla ilgili daha detaylı bilimsel araştırmalar yapmalıdır ve bunlar kaynak/yayın haline getirilmelidir. Ruhsal bozuklukları engellemeye yönelik eylemler ve politikalar temel insan haklarını koruma ayrıca geliştirme politikalarının ayaklarından bir tanesidir [65]. Bu nedenle politika üretimine sosyal hizmet uzmanları dahil edilmelidir.

Klinik/psikiyatrik sosyal hizmet uzmanı tanımının ve rollerinin ruh sağlığı alanında uygun bir yasal zeminde ve uluslararası (özellikle ABD ve gelişmiş $\mathrm{AB}$ ülkeleri örnek alınarak) tanımlanmalara uygun olarak yapılması önerilmektedir.

Makro düzeyde ruh sağlığı alanında klinik/psikiyatrik sosyal hizmet uzmanları için istihdam oluşturulması ve yaygınlaştırılması da bu alanın gelişebilmesi için [38] önem taşımaktadır. 
Ruh sağlığı hizmetine gerekli durumlarda hastanın çevresini oluşturan ailesinin ve diğer yakınlarının dahil edilmesinin tedavi protokolünde de tanımlanarak bunun işletilmesi sağlık hizmetindeki verimi artırabilir.

Ruh sağlığı hizmeti alan bireylerden gerekli görülenlerin ve özellikle sık relaps gösterenlerin sosyal incelemelerinin de yapılabilmesi için gerekli donanım ve aracın sosyal hizmet uzmanlarına sağlanması yine öneriler arasındadır. Bu sosyal incelemeler hastaların ihtiyaç duydukları kaynaklarla buluşturulmaları hususunda da etkili bir araç olabilecektir. Özellikle afet gibi kriz durumlarında sosyal incelemelerle ilgili ihtiyaç çok daha yoğun hissedilebilecektir.

Ruh sağlığı ekiplerinde görevli sosyal hizmet uzmanlarının makro düzeyde sosyal ve çevresel faktörlerin iyileştirilmesine yönelik etkili olabilmeleri veya önerilerini karar vericilere duyurabilmeleri için il/ilçe odaklı yerel yönetim meclis veya kurullarına doğal üyeler olarak entegre edilmelerinin de uygun olacağ düşünülmektedir.

\section{Referanslar}

1. Ocaktan, E, Özdemir, O, \& Akdur, R, Birinci basamakta ruh sağlığı hizmetleri, Kriz Dergisi, 2004, 12(2), 63-73.

2. Gültekin, B, Ruhsal bozuklukların önlenmesi: Kavramsal çerceve ve sinıflandırma, Psikiyatride Güncel Yaklaşımlar, 2010, 2(4), 583-594.

3. Güler, Ö, Altıntaş, K, Selvi, Y, Aydın, M, Ruh sağlığı ve hastalıkları; Nobel Tıp Kitapevi: Ankara, 2019, s.1.

4.WHO, World Health Organization. Constitution, 1948. Retrieved from: https://www.who.int/about/who-we-are/constitution

5. WHO, Risks to mental health: An overview of vulnerabilities and risk factors. Background paper by WHO secretariat for the development of a comprehensive mental health action plan; World Health Organization: Geneva, 2012. Retrieved from: https://pdfs.semanticscholar.org/bfbe/defc6db265ca474add283af034 e8f55cc4de.pdf?_ga=2.6259827.1988456599.1586549441968087484.1586549441

6. Akın, G, İnsan sağlığı ve çevre etkileşimi. Ankara Üniversitesi Dil ve Tarih Coğrafya Fakültesi Dergisi, 2014, 54(1), 105-116.

7. Özbesler, C, İçağasıoğlu Çoban, A, Hastane ortamında sosyal hizmet uygulamaları: Ankara örneği, Toplum ve Sosyal Hizmet, 2010, 21(2), 31-46.

8. Allen, R, The role of the social worker in adult mental health services. The college of social work the voice of social work in England: UK, 2014 Retrieved from: https://www.bl.uk/britishlibrary/ /media/bl/global/socialwelfare/pdfs/non-secure/r/o/l/role-of-the-social-worker-in-adultmental-health-services.pdf

9. Karakuş, B, Türkiye'de sosyal hizmet uzmanı sayıları ve istihdam açsından durumları 2015 Erisim Linki: http://www.shudernegi.org/?pnum=175\&pt=T\%C3\%BCrkiye\%27d eki+Sosyal+Hizmet+Uzman\%C4\%B1+Say\%C4\%B1lar\%C4\%B1

10. T.C. Sağlık Bakanlığı, Yönetim Hizmetleri Genel Müdürlüğ̈̈, Personel dağılım cetveli, 2020-Mart. Erişim Linki https://yhgm.saglik.gov.tr/TR,42988/personel-dagilim-cetvelipdc.htm

11. US Bureau of Labor Statistics, Occupational outlook handbook- 2018 datas, 2020. Retrieved from https://www.bls.gov/ooh/communityand-social-service/social-workers.htm\#tab-3

12. Grohol, J.M, Mental health professionals: US statistics-2017, 2019 Retrieved from: https://psychcentral.com/blog/mental-healthprofessionals-us-statistics-2017/

13. Salsberg, E, Quigley, L, Mehfoud, N, Acquaviva, K, Wyche, K, Sliva, S, Profile of the social work workforce report, 2017. Retrieved from: https://g6.psychcentral.com/blog/wpcontent/uploads/2019/04/Profile-of-the-Social-Work-Workforce.pdf

14. Kuzu, A, Çevik Durmaz, Y, Bireysel ve toplumsal açıdan ruh sağlığını etkileyen çevresel ve kültürel faktörler, İçinde Ünsal Barlas G (Ed.) Toplum Ruh Sağlı̆̆ Hemşireliği, Türkiye Klinikleri, Ankara, 2018 ss. $15-19$.
15. Bozan, M, Toplum ruh sağlı̆ğ merkezinden hizmet alanların içselleştirilmiş damgalanma ve sosyal işlevsellik durumlarının incelenmesi: Eskișehir örneği; Hacettepe Üniversitesi Sosyal Bilimler Enstitüsü, Yüksek lisans tezi: Ankara, 2019; s.2,6.

16. Oral, $\mathrm{M}$, Tuncay, $\mathrm{T}$, Ruh sağlığı alanında sosyal hizmet uzmanlarının rol ve sorumlulukları. Toplum ve Sosyal Hizmet, 2012, 23(2), 93-114.

17. Engin, E, Uğuryol, M, Kaçmaz, ED, Yalnızlık kavramı ve sağlıklı yaşam üzerine etkileri: gözden geçirme, Uluslararası Sosyal Araștırmalar Dergisi, 2016, 9(42), 1101-1105.

18. Kılavuz, M.A, Batı kültüründe yaşlanma dönemi yalnızlık duygusunu azaltma ve arkadaş ilişkilerini gelişsirme açısından dinî etkinliklerin önemi, Uludağ Üniversitesi İlâhiyat Fakültesi Dergisi, 2005, 14(2), 25-39.

19. Taşdemir, G, Yoksulluğun ruh sağlığı üzerine etkileri, International Journal of Human Sciences, 2014, 11(2), 74-87.

20. Jamison, J, McGee, KR, Oseni, G, Perng, J, Sato, R, Tanaka, T, Vakis $\mathrm{R}$, The relationship between conflicts, economic shocks, and death with depression, economic activities, and human capital investment in Nigeria. Poverty\&Equity Global Practice, Policy Research Working Paper 8685, 2018, p.3. Retrieved from: http://documents.worldbank.org/curated/en/647701545257537283/p df/WPS8685.pdf

21. Öz, F, Bahadır Yılmaz, E, Ruh sağlığının korunmasında önemli bir kavram: Psikolojik sağlamlık, Sağlık Bilimleri Fakültesi Hemşirelik Dergisi, 2009, 16(3), 82-89.

22. Seker, A, Sosyal dıslanma bağlamında sosyal teoride insan sorunu, İçinde İçağasıoğlu Çoban, A, Attepe Özden, S (Ed.) Psikiyatrik Sosyal Hizmet, Nobel Akademik Yay., Ankara, 2018, ss.19-40.

23. Polat, G, İç göçün çocuk ruh sağlı̆̆gna etkisi ve sosyal hizmet müdahalesi, Toplum ve Sosyal Hizmet, 2007, 18(1), 89-106.

24. Tuzcu, A, Ilgaz, A, Göçün kadın ruh sağlığı üzerine etkileri, Psikiyatride Güncel Yaklaşımlar, 2015, 7(1), 56-67.

25. Solgun, C, Durat, G, Göç ve ruh sağlığı, Journal of Human Rhythm, 2017, 3(3), 137-142

26. Kahil, A, Çırakoğlu, OC, Sarsıcı bir yaşam deneyimi olarak psikolojik travma, İçinde İçağasıŏlu Çoban, A, Attepe Özden, S (Ed.) Psikiyatrik Sosyal Hizmet, Nobel Akademik Yay., Ankara, 2018, ss.185-195.

27. Lotfi, S, Baş̧̧ılar M, Travma sonrası stres bozukluğu ve sosya hizmet, İstanbul Gelişim Üniversitesi Sağllk Bilimleri Dergisi, 2017. 3, 275-286.

28. Soygür, H, Özalp, E, Şizofreni ve damgalanma sorunu, Türkiye Klinikleri Dahili Tip Bilimleri Dergisi, 2005, 1(12), 74-80.

29. Güney, M, Ruhsal bozukluklarda stigmatizasyonu önlemek için neler yapılabilir, Kriz Dergisi, 2004, 12(1), 67-71.

30. Doğanavsargil Baysal, GÖ, Damgalanma ve ruh sağlığı, Arșiv Kaynak Tarama Dergisi, 2013, 22(2), 239-251.

31. Demirgöz Bal, M, Toplumsal cinsiyet eșitsizliğine genel bakıș, Kadın Sağ̆lı̆̆ Hemșireliği Dergisi, 2014, 1(1), 15-28.

2. Özel Doğana, H, \& Piyalb, B, Toplumsal cinsiyetle ilişkili sorunlar, Turkish Journal of Public Health, 2017, 15(2), 150-163.

33. Başar, F, Toplumsal cinsiyet eşitsizliği: kadın sağlığına etkisi, Doğum-Kadın Sağlığı ve Hastalıkları Hemşireliği, 2017, 8 (3), 131137.

34. Duyan, V, Hastaların karşllaştıkları sorunlar ve çözümleri odağında tıbbi sosyal hizmet, Cumhuriyet Üniversitesi Tip Fakültesi Dergisi, 2003, 25(4), 39-44.

35. Bulut, I, Psikiyatride ekip çalışması ve sosyal hizmet, İçinde İçağasıŏlu Coban, A, Attepe Özden, S (Ed.) Psikiyatrik Sosyal Hizmet, Nobel Akademik Yay., Ankara, 2018, ss.41-44.

36. Saruc, S, \& Duyan, V, Psikiyatride ekip çalıșması ve sosyal hizmet bakış açısı, Kriz Dergisi, 2009, 17(1), 37-44

37. Karadağ, F, Çocuk ve ergen ruh sağllğ̆ polikliniğinde sosyal hizmet uygulamaları, Uluslararası Sosyal Araștırmalar Dergisi, 2019, 12(62), 1426-1430.

38. Zubaroğlu Yanardă̆, M, \& Özmete, E, Bir mesleki uygulama alan olarak geçmişten geleceğe klinik sosyal hizmet, Toplum ve Sosyal Hizmet, 2017, 28(1), 203-225.

39. Sahin, F, Sosyal Hizmette Güçler Perspektifi ve Çözüm Odakl Mülakat, Aile ve Toplum, 2001, 1(4), ISSN: 1303-0256

40. Tuncay, T, Psikiyatrik Sosyal Hizmete Giriș, İçinde İçă̆asıoğlu Çoban, A, Attepe Özden, S (Ed.) Psikiyatrik Sosyal Hizmet, Nobel Akademik Yay., Ankara, 2018, ss.3-17

41. Cölgecen, Y, Psikiyatrik sosyal hizmet ve hastane - toplum ruh sağlığı merkezi uygulamaları (Manisa ili örneği), Yalova Üniversitesi Sosyal Bilimler Enstitüsü, Doktora Tezi: Yalova, 2018, s.47. 
42. Duyan, V, Sağlıkta psiko-sosyal boyut, Tibbi sosyal hizmet, 72TDFO Ltd Şti: Ankara, 1996, s.4.

43. Duru, S, Kalaycı, E, Kentleșme ve yoksulluk bağlamında sosya hizmet uzmanının mesleki rolleri, International Journal of Academic Value Studies, 2017, 3 (17), 224-230.

44. Duyan, V, Sayar, ÖÖ, Özbulut, M, Sosyal hizmeti tanımak ve anlamak. 1. Bask1, Ankara: Öncü Basım, 2008, s. 177.

45. Özdemir, U, Evsizlik ve evsizlere genel bir bakış, Toplum ve Sosyal Hizmet, 2010, 21(2), 77-88.

46. Yeter, A, Sivil toplum kuruluşlarının evsizlere yönelik hizmetlerinin değerlendirilmesi: İstanbul örneği, Yalova Sosyal Bilimler Dergisi, 2018, 17, 34-60

47. Demiröz, F. (2018). Ruh sağlığı alanında krize müdahale ve sosya hizmet uygulamaları, İçinde İçağasığlu Çoban, A, Attepe Özden, S (Ed.) Psikiyatrik Sosyal Hizmet, Nobel Akademik Yay., Ankara 2018, ss.265-281.

48. Tek, S, Irkçılık Karşıtı Sosyal Hizmet Uygulaması, Toplum ve Sosyal Hizmet, 2019, 30(3), 1142-1165.

49. Başer, D, Kırlıoğlu, M, \& Mavili Aktaş, A, Sosyal hizmet mesleğinin bir uygulama alanı olarak toplum temelli ruh sağlığı sistemi ve güncel değișimler, Toplum ve Sosyal Hizmet, 2013, 24(2), 179-192.

50. Bahar, G, Savaş, HA, Ruh sağlığı çalışmalarında sosyal hizmet mesleğinin rolü, Yeni Sempozyum Dergisi, 2013, 51(2), 83-90.

51. Nişancı, A, Ruh sağlığı alanında iyileşme yaklaşımı ve psikiyatrik sosyal hizmet, Toplum ve Sosyal Hizmet, 2019, 30(1), 231-259.

52. Büber, B, Kars, B, Gülsün, M, Nergizci, M, Sizofreniye yönelik damgalamanın önlenmesinde sosyal hizmet müdahaleleri bağlamında sosyal politika önerileri, Ufkun Ötesi Bilim Dergisi, 2014/2015, 14/15(1), 35-51.

53. Çiçekoğlu P, Duran S, Dünyada ve Türkiye'de toplum temelli koruyucu ruh sağlığı hizmetleri, İçinde Ünsal Barlas G, (Ed.) Toplum Ruh Sağlığı Hemşireliği, Türkiye Klinikleri, Ankara, 2018, s. 8-18.

54. Songur, C, Saylavcı, E, Kıran, Ș, Avrupa'da ve Türkiye'de ruh sağlı̆̆1 hizmetlerinin karşılaştırmalı olarak incelenmesi, Social Sciences Studies Journal, 2017, 3(4), 276-289.

55. Yanık, M, Türkiye ruh sağlığı sistemi üzerine değerlendirme ve öneriler: Ruh sağlığı eylem planı, Psikiyatride Derlemeler, Olgular ve Varsayımlar, 2007, (Ekim Özel Say1), 1-80.

56. Görmez, Y, Toplum ruh sağlığı merkezleri, İçinde İçağasıoğlu Çoban, A, Attepe Özden, S (Ed.) Psikiyatrik Sosyal Hizmet, Nobel Akademik Yay., Ankara, 2018, ss.259-264.

57. Australian Association of Social Workers- AASW, Scope of socia work practice social work in mental health, 2015 Retrieved from: https://www.aasw.asn.au/document/item/8309

58. Wilberforce, M, Abendstern, M, Batool, A, Boland, J, Challis, D, Christian, J, Hughes, J, Kinder, P, Lake-Jones, P, Mistry, M, Pitts, R, Roberts, D, What do service users want from mental health socia work? A best-worst scaling analysis. British Journal of Social Work, 2018. DOI Number: https://doi.org/10.1093/bjsw/bcz133

59. T. C. Sağlık Bakanlığı Toplum Ruh Sağlığı Merkezi Uygulama Rehberi, 2012.

60. T.C. Sağlık Bakanlığı, Ulusal Ruh Sağlığı Eylem Planı, Ankara 2011. Erişim Linki: https://dosyamerkez.saglik.gov.tr/Eklenti/30333,ulusal-ruh-sagligieylem-planipdf.pdf?0

61. Yesil, B, \& Hanalmıs, B, Bir ruh sağlığ hastanesinin bir eğitim ve araştırma hastanesinden içselleştirilmiş damgalanma düzeyi açısından farklılıkları, F. Ü. Sağlık Bilimleri Tıp Dergisi, 2016, 30(3), 125-129.

62. Küçükkaraca, N, Akçay, N, Sosyal hizmet bölümü öğrencilerinin ruhsal hastalığa yönelik inançlarının belirlenmesi, Toplum ve Sosyal Hizmet, 2017, 28(1), 27-45

63. İçağasığlu Çoban, A, Psikiyatrik sosyal hizmette güncel yaklaşımlar, İçinde İçağasıoğlu Çoban, A, Attepe Özden, S (Ed.) Psikiyatrik Sosyal Hizmet, Nobel Akademik Yay., Ankara, 2018, ss.361-370.

64. Keçeci, G, Makro sosyal hizmet uygulamasında kullanılan modeller, teknikler ve sosyal hizmet uzmanlarının rolleri, Toplum ve Sosyal Hizmet, 2017, 28 (1), 187-201.
65. WHO, Prevention of mental disorders: Effective interventions and policy options, Summary Reports. Geneva: WHO, 2004, p.14 Retrieved from: https://www.drugsandalcohol.ie/25604/1/prevention_of_mental_dis orders_sr.pdf

http://edergi.cbu.edu.tr/ojs/index.php/cbusbed isimli yazarın CBU-SBED başlıklı eseri bu Creative Commons Alıntı-Gayriticari4.0 Uluslararası Lisansı ile lisanslanmıştır.

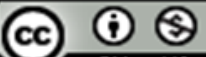

